\title{
Perishable and non-perishable food products roles in environment- A review
}

\author{
Vishal Kumar ${ }^{* 1}$, Suresh Chandra ${ }^{2}$, Kapil Kumar ${ }^{2}$, S.K. Goyal ${ }^{3}$, Lalit Kumar ${ }^{1}$ and Amit \\ Kumar $^{4}$ \\ Department of Food Technology, SVSU, Meerut (U.P.) ${ }^{1}$ \\ Department of Agric. Engg, SVPUAT, Meerut (U.P.) ${ }^{2}$ \\ KVK, Institute of Agric. Sciences, BHU, RGSC, Barkachha, Mirzapur (UP) ${ }^{3}$ \\ Shri Venkateshwara University, Gajraula ${ }^{4}$ \\ *Email: foodtechsite@gmail.com
}

\begin{abstract}
'Perishable' is a term used in the context of food that goes bad quickly. You must have noticed that if you keep the milk at room temperature, especially in hot summer, by evening it curdles. If you keep the dough in similar circumstances it ferments and soon starts giving foul smell. But nothing happens to bread or potatoes or apples or pulses. Bread will show signs of decay in probably 2-3 days times and potatoes and apples with take even longer. Pulses usually do not show any damage for months. Perishable foods are those likely to spoil, decay or become unsafe to consume if not kept refrigerated at $4.4{ }^{\circ} \mathrm{C}$ or below or frozen at $-17.8^{\circ} \mathrm{C}$ or below. Examples of foods that must be kept refrigerated for safety include meat, poultry, fish, dairy products, and all cooked leftovers. Refrigeration slows bacterial growth and freezing stops it. There are two completely different families of bacteria that can be on food: pathogenic bacteria, the kind that cause food borne illness, and spoilage bacteria, the kind of bacteria that cause foods to deteriorate and develop unpleasant odors, tastes, and textures. Perishable foods cannot be stored for more than one or two days at room temperature, that is, they have a shelf life of 1 or 2 days.
\end{abstract}

Key words: Perishable or non-perishable foods, storage, enzyme, temperature and package.

Paper cited: Kumar, V., Chandra, S., Kumar, K., Goyal, S.K., Kumar, L. and Kumar, A. (2017). Perishable and non-perishable food products roles in environment- A review. South Asian Journal of Food Technology and Environment, 3(1): 418-431.

\section{Introduction}

It is very much required to estimate the shelf-life of fruits stored in cold storage so the fruits could be cleared to market for consumption. Normally it is always not possible to adjudge the fruit quality individually to each rack in the cold storage, for, a vision system is required that could acquire the images of the shelf containing fruits and send the same to the monitor. However, images sending to monitor is not sufficient. Rather, an algorithm is required that could process the images and tell the quality of the fruits on-line. In the proposed work, a noval algorithm is presented that can estimate the storage life of the fruits under scanner and present quality to the storage manager who can take the required action to proceed. Non- perishable foods have a long shelf life and don't require refrigeration. Food drives for homeless shelters or disaster response efforts primarily request non-perishable food items. If you are stocking your own emergency preparedness kit, include a variety of non-perishable food items to keep your family fed during a disaster. For example canned food, dry foods and dehydrated foods etc. Campers and survivalists often bring dehydrated foods, originally developed for the military, on their trips. Also called MREs, or "meals ready to eat," the pouches contain fullycooked food you can eat as-is or warm and rehydrate with boiling water. Dehydrated foods work well in emergency kits because they are 
compact and can be stored for many years. The algorithm's accuracy primarily depends upon the image acquisition system so that, no surrounding noise due to illumination is not entered into the image that may lead to wrong results. Further, the acquired images are pre-processed to enhance the vision and exposed to feature extraction process, on the basis of which the shelf-life is computed. Some post-harvest food wastage and losses are inevitable in FSC network links (Thompson 2002; Widodo et al., 2006 and Gustavsson et al., 2011).

Murthy et al., (2009) reported that a huge amount of food is wasted in various stages of the FSC. According to FAO report, the amount of post-harvest loss ranges from 20 to 60 percent of the total production across countries and roughly one-third of food produced for human consumption is lost or wasted globally, which amounts to about 1.3 billion tons per year (Manish and Jharkharia, 2013). There is an increased food demand in the globe, so increasing food production is one way to fulfill the need, in addition, waste reduction at every stage of the food supply chain can be also an option to get advantage from the increased production. Major operational causes of waste are inefficiencies in production, storage, handling, and transportation (Murthy et al., 2009). In addition, lack of proper planning and management practices in food supply chain can be the major operational cause in different countries. In developing countries farmers are small land holders and share croppers and have little knowledge of technology, market demand, and financial incentives also considered as the cause (Lipinski et al., 2013).

Food preservation involves preventing the growth of bacteria, fungi (such as yeasts), or other micro-organisms (although some methods work by introducing benign bacteria or fungi to the food), as well as retarding the oxidation of fats that cause rancidity. Food preservation may also include processes that inhibit visual deterioration, such as the enzymatic browning reaction in apples after they are cut during food preparation. Many processes designed to preserve food will involve a number of food preservation methods. Preserving fruit by turning it into jam, for example, involves boiling (to reduce the fruit's moisture content and to kill bacteria, etc.), sugaring (to prevent their regrowth) and sealing within an airtight jar (to prevent recontamination). Some traditional methods of preserving food have been shown to have a lower energy input and carbon footprint, when compared to modern methods.

Refrigeration is employed to control the rate of certain chemical and enzymatic reactions as well as rate of growth of food microorganisms (Srivastava and Kumar 2002). Food spoilage slows down as molecular motion slows which retards growth of bacteria that causes food to spoil (Whitman et al., 2005). However, studies have shown that perishable food will deteriorate, even at refrigerator temperature, due to spoilage because of microorganisms, enzymes and oxidation (Jay, 2000). Type of container or wrapping material they are stored in and duration of storage are also important factors that influence the type of microbial growth, toxicity and spoilage of food during refrigerated storage. Although low temperature retards spoilage but even a subfreezing temperature of about $7^{\circ} \mathrm{C}$ does not prevent multiplication of all microorganisms. Refrigerated foods are therefore subjected to spoilage by moulds, yeasts and bacteria (Roday, 2002).

\section{Perishable Foods}

Perishable foods are those likely to spoil, decay or become unsafe to consume if not kept refrigerated at $40 \mathrm{~F}^{\circ}\left(4.4^{\circ} \mathrm{C}\right)$ or below or frozen at $0 \mathrm{~F}^{\circ}\left(-17.8{ }^{\circ} \mathrm{C}\right)$ or below. Examples of foods that must be kept refrigerated for safety include meat, poultry, fish, dairy products, and all cooked leftovers. Refrigeration slows bacterial growth and freezing stops it. There are two completely different families of bacteria that can be on food: pathogenic bacteria, the kind that cause food borne illness, and spoilage bacteria, the kind of bacteria that cause foods to deteriorate and develop unpleasant odors, tastes, and textures. 


\section{Semi-perishable Foods}

It can be kept for a couple of weeks or even a month or two. They have a longer shelf life than perishable foods. Potato, arbi, onions, ginger, biscuits and namkeens, are some examples of semi-perishable food. Within packaging plastics for plant products, if commodity and film permeability characteristics are properly matched, an appropriate atmosphere can evolve passively through consumption of $\mathrm{O}_{2}$ and production of $\mathrm{CO}_{2}$ during respiration (Mir and Beaudry, 2002).

\section{Non-perishable Foods}

In the real sense, foods in this category are not really none-perishables, but they can be stored for much longer time as compared to perishables and semi-perishables. They can be stored for several months and the examples of such foods are cereals, pulses, dry fruits, spices, oil etc.

\section{Selection and Purchase of Food Products for Storage}

What do you do when you go to the market to buy food? You probably quickly run your fingers through wheat, rice, dal, etc., you press a tomato, mango or banana gently to see if it is firm. Why do you do this? You do this to assess the quality of food item. You generally buy more than what you need or what you can consume immediately. Buying food that spoils before you could use, it would mean wastage of money. The food that you purchased could also spoil if it is not stored properly. This again would mean wastage of food and money. If you leave dals or spices in paper bags, they will absorb moisture and then after sometime fungus and small insects will grow on them. Biscuits would become soggy and loose namkeens would lose their freshness. This means that proper storage of foodstuff is as important as the purchase of quality foodstuff. Let us now learn what we must keep in mind while selecting and purchasing food and the methods of storing different foodstuff. Milk products containing amorphous carbohydrates can undergo physical changes such as crystallization, clumping, sticking and caking during processing, handling and storage. Such physical changes lead to deterioration of food quality and increase relative humidity (Passmore and Eastward, 1986).

\section{Effect of Microorganisms}

Many diseases are caused by microorganisms, such as bacteria, viruses and parasitic infestations arising out of food spoiled due to prolonged storage of perishable and semi perishable food items. Like Staphylococcus bacteria which produces a toxic as by-product of growth and multiplication and cause food intoxication (Haghi, 2011).

They settle on the outer layer of foods and produce certain chemicals leading to spoilage of food. If this food is consumed it may lead to harmful effects. Microorganisms can be in anyone of these forms: bacteria, yeasts or moulds. Some micro-organisms are beneficial also. For example, how do you prepare curd at home? You just add some old curd into warm milk and after a few hours the curd is set. How did this happen? This change of milk to curd also takes place by the action of micro-organisms called bacteria. Formation of spongy texture in idli, dhokla, dosa, bread, etc., is also due to the action of microorganisms like yeast. Remember, such action of micro organisms is not spoilage of food.

Rhonda et al., (2012) examined the effect that recovery of culled produce from grocery stores has on the quantity of fresh fruits and vegetables available in meals served by one relief agency in Boulder, Colorado. Boulder Food Rescue uses a just-in-time model to recover fragile, highly perishable produce that is frequently not collected by traditional food rescue and relief organizations and delivers it directly to recipients. One of those recipients, Bridge House, is a day shelter that serves approximately 1,000 meals a week to homeless and working poor individuals. These two organizations recorded the ingredients and the donor of those ingredients in each Bridge House meal served for eight weeks (February and March, 2012). Boulder Food Rescue contributed 
$600 \mathrm{lbs}$ of produce a week, representing $66 \%$ of the fresh fruits and vegetables served, equivalent to between two and three servings of fruits and vegetables per meal, and was the only food rescue source for many of these items. Results show that the just-in-time food rescue model can supplement traditional food relief organizations by supplying fresh fruit and vegetables in the winter months when it would have been otherwise cost prohibitive.

\section{Effect of Insects and Rodents}

Leave dal, rice, wheat outside for a few days. What happens, if grains are not stored properly? They can be easily attacked by insects and rodents. They spoil food, not only by eating the food but also by dropping their excreta. Such foods are totally unfit for human consumption and get wasted. Besides, there are other factors which speed up the process of food spoilage. These are heat, moisture and air which help in speeding the growth of micro-organisms which spoil the food. You must have noticed that cooked food spoils faster in summer than in winter. This is because of the presence of heat and moisture in the air. You can keep dry food safely for a very long time because there is no moisture in them and therefore microorganisms cannot work on it. Food that gets spoilt is not fit for human consumption.

Kamalpreet (2015) showed that the fruits are merely identified by their shape and color based features. However, the algorithm does not support of there is any ripening issue or any infection due to the disease. This leads to an incomplete picture of the fruit condition. If the algorithm is enriched by the complete information about the fruit then it can be a fruitful report that will help in segmenting the fruits into different grades of quality and therefore costing can be done as well in the same accordance. This problem has been considered in the proposed research work. Main aim of the research is to develop a new and efficient algorithm for identify the quality of fruits. The goal will be achieved through the attainment of following objectives: Fruit quality extraction in terms of its shape, size and ripen stage, Fruit stage with respect to any disease, Penetration of disease into the fruit and Final fruit quality. A k-means clustering for color extraction and statistical features like area, radii and perimeter are used for estimation of fruit quality.

Silvia (2012) analyzed the current Spanish tariff system as applied by low-temperature distribution companies on transport in part loads of perishable freight that are destined to Spain's main European export markets. Using 2008 data that have been directly obtained from a sample of transport companies, the price structure is formulated by making a distinction between ordinary and final prices and their respective variables. Next, the price structure is compared to the mean production costs. According to our calculations, we can state that the tariffs of distribution companies depend on the mean total cost, and they are estimated by using final prices calculated expressly for every customer. Finally, this paper outlines directions for future empirical work.

\section{Effect of Environmental Causes}

Biological (internal) causes of deterioration include respiration rate, ethylene production and action, rates of compositional changes (associated with color, texture, flavor, and nutritive value), mechanical injuries, water stress, sprouting and rooting, physiological disorders, and pathological breakdown. The rate of biological deterioration depends on several environmental (external) factors, including temperature, relative humidity, air velocity, and atmospheric composition (concentrations of oxygen, carbon dioxide, and ethylene), and sanitation procedures. All these factors have been discussed by numerous authors (Bartz, 2002; Bourne, 1977; Bourne, 1983; Coursey 1983; Gross et al., 2002; Harvey, 1978; Kader, 1983; Kader, 2002; Musa, 1984; Tindall and Proctor, 1980). 


\section{Socioeconomic Factors}

Although the biological and environmental factors that contribute to postharvest losses are well understood and many technologies have been developed to reduce these losses, they have not been implemented due to one or more of the following socioeconomic factors (Kader, 1983).

\section{Strategies for Reducing Postharvest Losses}

A systematic analysis of each commodity production and handling system is the logical first step in identifying an appropriate strategy for reducing postharvest losses (Bell et. al., 1999). Also, a cost-benefit analysis to determine the return on investment in the recommended postharvest technologies is essential (for information on how to conduct such analyses, see. It is important to select the technologies that are appropriate for the size of each postharvest enterprise (Clarke, 1994; Kitinoja and Gorny, 1999; Kitinoja and Kader, 2002; Persson, 1986). Marketing companies and cooperatives are essential for handling produce and reducing postharvest losses by providing facilities for accumulating, preparing and transporting produce to markets; by coordinating marketing activities; and by distributing profits equitably to members.

\section{Supply of Perishable and Non-perishable Food}

However, to provide a good quality of product we cannot ignore one important issue, consideration logistics. Especially when transporting perishable food (milk, fish, fruit, fresh bakery) or medical products (Fearne, 1999), it is an important consideration that foods are shipped from raw material to manufactory or manufactory to distribution centers, distribution centers to final users (Mattoli et al, 2010). When shipped food in a long distance, it has an influence on every step in cold logistics. According to the (Changsheng, 2007) definition of food cold chain, logistics system is a process including product, storage, delivery and final users.
By reviewing the literature, there are few relevant articles, which provide analysis about cold chain logistics cost and logistics effectively. The main factor for a good cold chain logistics is using technology equipment to monitor the goods' conditions during the different logistics phases. (Mattoli et al., 2010; Montanari's, 2008). But in that case, how to balance the cost and effectiveness would be a new field to research. According to (Boronico 1995), reduction in the total cost could be the challenging goal in most sectors of business. The cost influences many factors in logistics, e.g. transportation, the stocking, the labor cost (Kelepouris et al., 2007; Boronico and Bland, 1995; Wagner and Alderdice, 2006; Manikas et al., (2009) also stated that the low effectiveness impends the way on fresh food logistics, furthermore that results in low utilization and operational performance.

For perishable foods like fruit, milk, fresh cakes, which need an extreme monitoring of temperature and humidity, It is necessary to have information of traceability, for describing the history of production of a food produce, and any subsequent transformations or processes that the food might be figured during the progress from the raw materials to semi- product or finished goods. In order to achieve this, efficient collection, storage, transmission in real-time, and information management are required by food industry (Mangina and Vlachos, 2004). The figure 5 below shows the applicative of FTD on food logistics. An integrated system of quality and safety requires a strict level on tracing, which involves all of the stakeholders among the supply chain to increase consumer confidence in products aspect by making monitoring data accessible to the consumer (Shanahan et al, 2008). Then insure the quality and safety in FSC system. For further developing and progress in sustainability, studies on shelf life and monitoring of the time temperature are integrated into the "Shelf Life Decision System", which has been proved as a high efficiency tool for food chill chain management leading to optimization of food 
quality at customers' end. Heuristics is a simplification process that attempts to quickly find a good solution to a decision problem. Decision makers recognize patterns in the situations they face and apply rules of appropriate behavior to those situations (Shapiro, 2006).

However, as their modeling styles may be different and possibly incompatible, the issue of problem formulation may perhaps exist (Hooker, 2011). Mathematical programming methods provide powerful and comprehensive tools for accommodating large quantities of numerical data describing the SCs. Simulation is commonly used for scenario generation and analysis (Srivastava, 2007). It permits managers and analysts to study the dynamic behavior of an SC with an easier decision logic employed than that of a mathematical programming model (Shapiro, 2006). The simulation model has already been proven to be useful for measuring the bullwhip effect (Min and Zhou, 2002). Some recent approaches look at temperature and its influence on quality degradation of perishable food in relation to sustainable SCs (Van der Vorst et al., 2009, Rong et al., 2011).

The functionality/physical fitness deterioration includes spoilage for perishable food products, decay for radioactive substances, degradation for electronic components, loss of potency for photographic films and pharmaceutical drugs, and physical depletion for pilferage or evaporation of volatile liquids such as gasoline and alcohol. An item is considered perishable if it requires specific storage conditions to slow down the high deterioration rate when at ambient, i.e. room temperature, storage conditions (Van Donselaar et al., 2006). Perishable goods can be seen as items with a fixed, maximum lifetime when they become obsolete at some point in time due to their nature or external factors that predetermine their shelf lives. However, most authors working in the field of deterioration and perishability use these terms interchangeably (Pahl and Voß, 2014).

\section{References}

1. Bartz, J. A. and Brecht, J. K. (2002). Postharvest physiology and pathology of vegetables, 2nd ed. Marcel Dekker, New York.

2. Bell, A., Mazaud, F. and Mück, O. (1999). Guidelines for the analysis of postproduction systems. FAO, Rome, Italy, p 102.

3. Boronico J.S., and Bland D.J. (1995). Customer service: the distribution of seasonal food products under risk, International Journal of Physical Distribution \& Logistics Management, Vol. 26 No. 1, pp. 25-39.

4. Bourne, M.C. (1977). Post-harvest food losses - the neglected dimension in increasing the world food supply. Cornell University International Agriculture Mimeograph No. 53.

5. Bourne, M.C. (1983). Guidelines for postharvest food loss reduction activities. United Nations Env. Prog., Ind. \& Env. Guidelines Series.

6. Changsheng B. (2007). On operation management of cold chain. Scientific article, Tongji University: China.

7. Clarke, B. (1994). Conference Proceedings: Appropriate postharvest technology for developing countries. Postharv. News Info $5: 27 \mathrm{~N}-38 \mathrm{~N}$.

8. Coursey, D.G. (1983). Postharvest losses in perishable foods of the developing world. p. 485-514. In: M. Lieberman (ed.), Postharvest Physiology and Crop Preservation. Plenum Publ. Corp., New York, NY.

9. Fearne A., and Hughes D. (1999). Success factors in the fresh produce supply chain: insights from the UK. Supply Chain Management, Vol. 4., No. 3, pp. 120-128.

10. Gross, K., Wang, C.Y. and Saltveit, M.E. (2002). The commercial storage of fruit, 
vegetables and florist and nursery stocks. USDA Agr. Handb. 66

11. Gustavsson, J.; Cederberg, C. and Otterdijk, R. (2011). "Global Food Losses and Food Waste," in The food and agriculture organization of the United Nations, Rome, Italy.

12. Haghi, A. K. (2011). Food Science: Research and Technology. Canada: Apple Academic Press Inc.

13. Harvey, J.M. (1978). Reduction of losses in fresh market fruits and vegetables. Annu. Rev. Phytopathol. Vol.16, pp 321-341.

14. Hooker, J. (2011). Logic-based methods for optimization: combining optimization and constraint satisfaction, John Wiley \& Sons.

15. Jay, M. J. (2000). Food Analysis: Theory and Practices. $3^{\text {rd }}$ Edition. New Delhi: CBS Publishers and Distributors,

16. Kader, A.A. (1983). Postharvest quality maintenance of fruits and vegetables in developing countries. p. 455-570. In: M. Lieberman (ed.), Postharvest Physiology and Crop Preservation. Plenum Publ. Corp., New York, NY.

17. Kader, A.A. (2002). Postharvest technology of horticultural crops. 3rd ed. Univ. Calif. Agr. Nat. Resources, Oakland, Publ. 3311.

18. Kamalpreet Kaur and Preeti Gulati (2015). Shelf life estimation of perishable fruits in cold storage using image processing techniques. International Journal of Advanced Research in Coumpter Sciences and Software Engineering. Vol.05, No 04; pp 1289- 1291.

19. Kelepouris T., Pramatari K. and Doukidis G., (2007). RFID-enabled traceability in the food supply chain, Industrial Management and Data system, Vol. 107, No. 2, pp 183200.

20. Kitinoja, L. and Kader, A.A. (2002). Smallscale postharvest handling practices: a manual for horticultural crops. 4th ed. Univ. Calif. Postharvest Hort. Series No. 8E.
21. Lipinski, B.; Hanson, C.; Lomax, J.; Kitinoja, L.; Waite, R. and Searchinger, T. (2013). Reducing Food Loss and Waste. Working Paper, Installment 2 of Creating a Sustainable Food Future," World Resources Institute, Washington, DC.

22. Mangina E. and Vlachos I. P., (2004). The changing role of information technology in food and beverage logistics management: beverage network optimization using intelligent agent technology, Journal of Food engineering, Vol. 70, pp 403-420.

23. Manish, S. and Jharkharia, S. (2013). Agrifresh produce supply chain management: a state-of-the-art literature review. Vol. 33, No. 2, pp. 114-158.

24. Mattoli, V., Mazzolai, Mondini,.A, Stefano Zampolli and Dario. P. (2010). Flexible tag datalogger for food logistics, Sensors and Actuators, Vol. A 162, pp. 316-323.

25. Min, H. and Zhou, G. (2002). Supply chain modeling: past, present and future. Computers \& Industrial Engineering, Vol.43, pp 231-249.

26. Mir, N., and Beaudry, R. M. (1986). Modified Atmosphere Packaging. USDA Handbook 66.

27. Montanari R, (2008). Cold Chain tracking: a managerial perspective, Trends in Food Science \& Technology, Vol. 19, pp. 425431.

28. Murthy, D.; Sudha, M. and Gajanana, T. (2009). "Marketing and Post-harvest Losses in Fruits: its applications on availability and economy," Vol. 64, No. 2.

29. Musa, S. K. (1984). Reduction of postharvest losses in vegetables and fruits in a developing country. p.165-176.

30. Pahl, J. and VOß, S. (2014). Integrating deterioration and lifetime constraints in production and supply chain planning: A survey. European Journal of Operational Research, Vol. 238, pp 654-674. 
31. Passmore R, Eastwood M. A. (1986). Human Nutrition and Dietetics. Edinburgh: Churchill Livingstone, p. 15.

32. Persson, P.O. (1986). Refrigeration and the world's food supply-especially in developing countries. Int. J. Refrig. Vol 9, pp 144-149.

33. Rhonda Hoenigman; Caleb Phillips; Shari Leyshon and Becky Higbee, M. D. (2012). Nutrition and very-perishable food rescue. Throughout the year.

34. Roday, N. (2002). Food Hygiene and Sanitation. New Delhi: Tata McGraw Hill Publishing Co Ltd.

35. Rong, A., Akkerman, R. and Grunow, M. (2011). An optimization approach for managing fresh food quality throughout the supply chain. International Journal of Production Economics, Vol 131, pp 421429.

36. Shanahan C, Kernan B, Ayalew G, McDonnell K, Butler F and Ward S, (2008). A framework for beef traceability from farm to slaughter using global standards: An Irish perspective, Computers and Electronics in Agriculture. Vol. 66, pp. 62-69.

37. Shapiro, J. (2006). Modeling the supply chain, Cengage Learning.

38. Silvia, Andres Gonzalez-Moralejo, (2012). Regregeration logistics operations and perishable costs in groupage loads: an application for Spanish exports in Europe. Ciencia a Investigacion Agraria.Vol.39, No. 02, pp: 265- 278.

39. Srivastava R. P. and Kumar S. (2002). Fruit and Vegetable Preservation: Principles and Practices. Lucknow: International Book Distributing Co.

40. Srivastava, S. K. (2007). Green supply-chain management: A state-of-the-art literature review. International Journal of Management Reviews, Vol. 9, pp 53-80.
41. Thompson, J. (2002). "Waste management and cull utilization," Agriculture \& Natural Resources, CA.

42. Tindall, H.D. and Proctor, F.J. (1980). Loss prevention of horticultural crops in the tropics. Prog. Food Nutr. Sci. Vol 4, No (34): pp 25-40.

43. Van Der Vorst, J. G., Tromp, S.-O. And zee, D.-J. V. D. (2009). Simulation modelling for food supply chain redesign; integrated decision making on product quality, sustainability and logistics. International Journal of Production Research, Vol.47, pp 6611-6631.

44. Van Donselaar, K., Van Woensel, T., Broekmeulen, R. and Fransoo, J. (2006). Inventory control of perishables in supermarkets. International Journal of Production Economics, Vol.104, pp 462472.

45. Whitman, W. C., Johnson W. M. and Tomczyk J.A. (2005). Refrigeration and Air Conditioning Technology. $5^{\text {th }}$ Edition. New Delhi: Thomson Publications.

46. Widodo, M.; Nagasawa, H.; Morizawa, H. and Ota, K. (2006). A periodical flowering harvesting model for delivering agricultural fresh products. European Journal of Operational Research, pp. 24-43.

$\begin{array}{ll}\text { Received } & \text { : March, 2017 } \\ \text { Revised } & \text { : April, 2017 } \\ \text { Published } & \text { : June, 2017 }\end{array}$

